\title{
ARTERIAL CALCIFICATION IN ASSOCIATION WITH A CONNECTIVE TISSUE DISORDER
}

\author{
BY \\ D. H. A. BOYD AND J. M. RAWLES \\ Caithness Central Hospital, Wick, Caithness
}

Arterial calcification in a 17-year-old youth is uncommon and, when associated with a number of clinical features suggesting a diffuse connective tissue disorder, is of sufficient interest to warrant the following case report.

\section{Case Report}

In August, 1963, at the age of 16 years the patient developed diarrhoea with a little blood but no mucus. When admitted to a general hospital in September he had a low grade pyrexia, haemoglobin (Hb) $8 \cdot 8 \mathrm{~g}$. per cent., and erythrocyte sedimentation rate (ESR) $70 \mathrm{~mm}$. in the first hour. A barium enema report stated, "the appearances are those of an early ulcerative colitis", and sigmoidoscopy showed a "congested and friable mucosa suggesting a rectosigmoiditis". Treatment was started with sulphasalazine, chloramphenicol, and sedatives, but shortly after this his stool culture grew Salmonella Tennessee and he was transferred to an infectious diseases hospital.

Despite the use of a number of antibiotics he continued to have profuse diarrhoea. Prednisolone was given in a dose of $15 \mathrm{mg}$. daily for a week and $10 \mathrm{mg}$. daily for a further 3 weeks during the month of September without effect. In November, 1963, he developed pain and swelling of both knees with joint effusion. Although culture for tubercle bacilli was negative, guinea-pig inoculation of the aspirate from one joint killed the animal with progressive tuberculosis. Radiologically the joint was normal and no evidence of tuberculosis elsewhere was obtained. Nevertheless anti-tuberculous chemotherapy was started and continued for a total of 8 months with no initial improvement. Because of his continued diarrhoea and poor general condition, he was transferred to a surgical unit in May, 1964, with a view to possible ileostomy or colectomy. It was decided, however, to assess the effects of higher doses of steroids, and a course lasting a month starting with $60 \mathrm{mg}$. daily resulted in considerable improvement. On discharge from hospital in August, 1964, he was reasonably well. Salmonella Tennessee had persisted intermittently in the stool for about a year but in the past 18 months stool cultures had been consistently negative.
In March, 1965, he complained of pain and swelling in both ankles and at that time routine $x$ rays of these joints showed calcification in the anterior and posterior tibial arteries (Fig. 1). This was subsequently seen in the femoral and popliteal vessels, but not in the vessels of the trunk, head, neck, or upper limbs. Both parents were $x$ rayed but neither showed arterial calcification. The patient has only one sibling, a sister, who is in good health and lives in Canada.

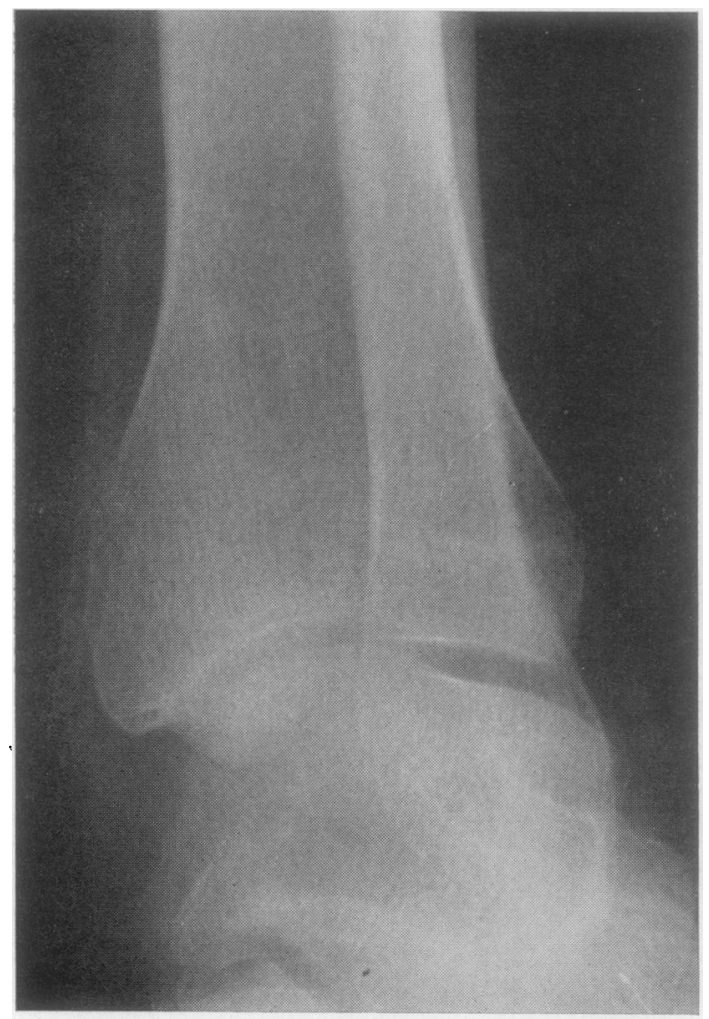

Fig. 1.-Radiograph of the left ankle, showing calcification of anterior and costerior tibial arteries. 
He was re-admitted to hospital in August, 1965, when he was having up to six watery motions per day, and had developed swelling of both legs. He had shown a marked reaction to sunlight a few weeks before and, although the skin reaction was fading, there was still considerable erythema, scaling, and pigmentation of hands and face. He had gross oedema of both legs and of the anterior abdominal wall. Clinically and radiologically there was a right-sided pleural effusion.

The following investigations were undertaken:

Hb 12 g. per cent.

Packed cell volume 41 per cent.

Mean corpuscular haemoglobin concentration 29 per cent.

White cell count $11,850 / \mathrm{cmm}$., differential count showing a polymorph leucocytosis.

ESR $105 \mathrm{~mm}$. in the first hour.

Latex test for LE phenomenon negative.

Fluorescent test for anti-nuclear factor negative.

Waaler-Rose titre less than $1: 16$.

Serum albumin $1.4 \mathrm{~g}$. per cent., globulin $1.7 \mathrm{~g}$. per cent., the electrophoretic pattern showing a rise in the beta globulin band.

Serum urea $24 \mathrm{mg}$. per cent., cholesterol $205 \mathrm{mg}$. per cent., calcium $8.8 \mathrm{mg}$. per cent., inorganic phosphate $4 \mathrm{mg}$. per cent., electrolytes normal.

Bilirubin $0.2 \mathrm{mg}$. per cent.

Alkaline phosphatase $8 \cdot 3$ units per cent.

Thymol turbidity $1 \cdot 4$ units.

The urine contained protein (8 parts Esbach) but no excess porphyrins were detected.

A 3-day collection of faeces showed a daily fat excretion of under $5 \mathrm{~g}$. and the d-xylose absorption test was normal.

Sigmoidoscopy to $20 \mathrm{~cm}$. showed a granular mucosa which bled easily and excess mucus was present.

Barium meal and follow through normal.

Muscle biopsy reported as follows (Dr. H. G. Richmond). "This muscle biopsy is characterized by atrophy of muscle fibres, with loss of normal staining reactions, variable thinning of the fibres, and occasional evidence of sarcolemmal proliferation. There is no round cell infiltration and no change in the vessels. Staining for amyloid has been negative."

Treatment with prednisolone $60 \mathrm{mg}$. daily was started on September 2, 1965. He had a satisfactory diuresis with disappearance of oedema and pleural effusion, and disappearance of the bowel symptoms. Serum albumin rose to $2.7 \mathrm{~g}$. per cent., serum globulin to $3.5 \mathrm{~g}$. per cent., and haemoglobin to $15 \mathrm{~g}$. per cent. The serum cholesterol, however, rose to $780 \mathrm{mg}$. per cent. and protein persisted to a lesser extent in the urine. Prednisolone therapy was eventually reduced to a maintenance dose of $10 \mathrm{mg}$. daily on which the patient remained clinically well. After some 6 months of corticosteroid therapy the arterial calcification appeared to be much less, and in places to have disappeared (Fig. 2).

Two years after beginning continuous corticosteroid treatment (the present dose of prednisolone being $5 \mathrm{mg}$. daily) the patient has no bowel symptoms and is well enough to undertake a light job. Only minimal ankle oedema is present, blood pressure is normal, and only a trace of protein is present in the urine. The haemoglobin

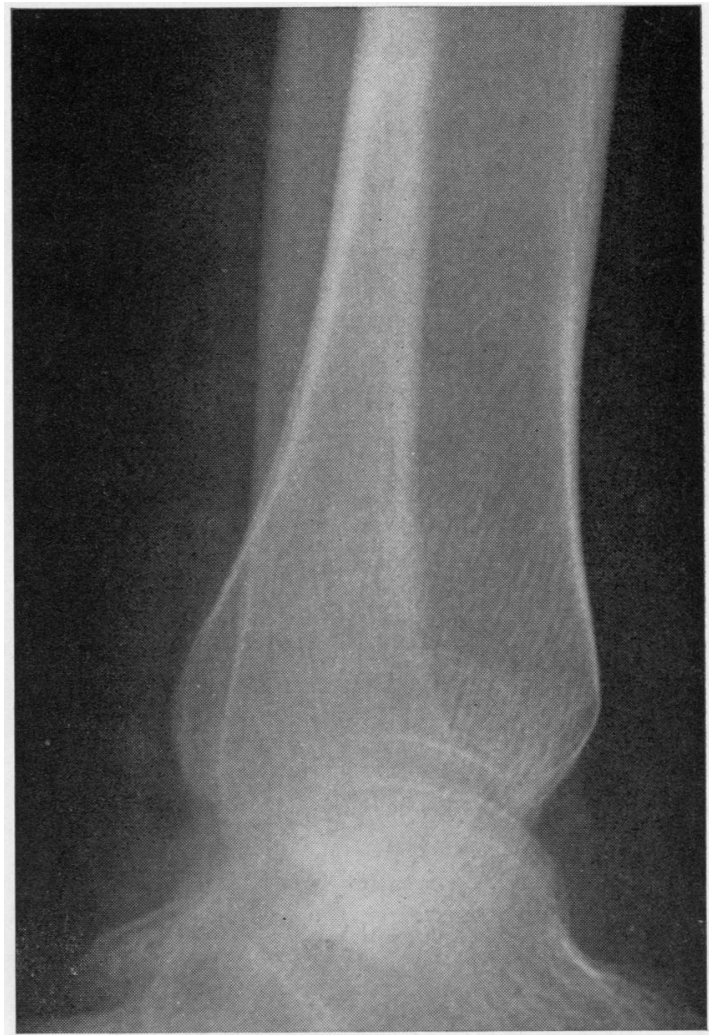

Fig. 2.-Radiograph of the same ankle 13 months later, showing disappearance of the calcification.

level is $14.4 \mathrm{~g}$. per cent., ESR $35 \mathrm{~mm}$. in the first hour, serum cholesterol $246 \mathrm{mg}$. per cent., urea $16 \mathrm{mg}$. per cent., albumin $3 \cdot 5 \mathrm{~g}$. per cent., and globulin $1 \cdot 8 \mathrm{~g}$. per cent.

\section{Discussion}

There are two features of this case, namely the isolation of Salmonella Tennessee from the stools and the death of the guinea-pig with tuberculosis after inoculation with joint aspirate, which are not easily related to the clinical picture. Salmonella Tennessee is usually associated with food poisoning-like symptoms and it is difficult to reconcile its presence with the clinical picture and radiological and sigmoidoscopic appearances described. No evidence can be offered as to the source of this organism in this particular case; this is the only recorded instance of its occurrence in the North of Scotland in the past 8 years. It is tempting to suggest, therefore, that this was an intercurrent infection during the course of a non-specific ulcerative condition of the colon. It has been stressed that there has been no clinical or radiological evidence of tuberculosis in any system at any time and it is doubtful if there had 
been any clinical response to anti-tuberculous chemotherapy. Although the organism was certainly Mycobacterium tuberculosis, its relation to the patient's illness and in particular to the joint symptoms is by no means clear. Arthropathy with joint effusion is known in a number of connective tissue disorders and in ulcerative colitis.

Arterial calcification in youth is rare. The occurrence of generalized arterial calcification of unknown aetiology in infancy is well documented (Hunt and Leys, 1957; Meurman, Somersalo, and Tuuteri, 1965; Ivemark, Lagergnen and Ljungqvist, 1962), but has always been associated with early death. Hudson (1965) refers to this condition, but otherwise arterial calcification is mentioned only in association with atheroma and Monckeberg's disease, which "occurs in adults and progresses with age". On the other hand, Gardner (1965) stresses that arteritis is a feature of connective tissue disorders, such as rheumatoid arthritis, rheumatic fever, disseminated lupus erythematosus, polyarteritis nodosa, and temporal arteritis, and that calcium deposits occur in dermatomyositis and systemic sclerosis usually in skin and muscle. Pseudoxanthoma elasticum is also mentioned by Gardner as being sometimes associated with arterial calcification, but there has been no evidence that this patient suffers from this disease. There seems little reasonable doubt on clinical grounds that the patient had a connective tissue disease, although of which type there is no proof. The serological tests and muscle biopsy carried out at the onset of the nephrotic syndrome were unhelpful. Later in the course of the disease and after corticosteroids had been given for 7 months, Dr. Deborah Doniach of the Middlesex Hospital Medical School kindly carried out tests for thyroid and gastric autoantibodies and anti-nuclear factors in the patient's serum with negative results.

Nevertheless, if it is accepted that the patient had a connective tissue disorder it becomes easier to accept the possibility of arteritis. Calcification remains a stumbling block and only one reference has been found which describes anything comparable. This is a case reported by Forsyth (1960) of a 9-year-old girl with severe rheumatoid arthritis and amyloidosis who was found to have calcification of the digital blood vessels (presumably arterial). In discussing the aetiology of this, the author considered and dismissed several possibilities, including amyloidosis, severe chronic renal disease, pseudoxanthoma elasticum, hypervitaminosis $\mathrm{D}$, idiopathic arterial calcification of infants, and hormonotherapy. She concluded "that prolonged immobilization led to decalcification of the skeleton with liberation of calcium which became deposited in digital vessels possibly damaged by rheumatoid disease". It is interesting that over a 3-year period, with increasing mobilization and continuing prednisolone therapy, the child achieved recalcification of the skeleton and diminution in the calcification of the digital vessels.

In the case described here it is possible that a similar mechanism has been in operation. The patient had been bed-ridden for about 18 months, and therefore might have had decalcification of bone although the incomplete skeletal radiographs taken at the time arterial calcification was discovered did not show any gross abnormalities. No calcium balance studies were undertaken. Although there is no proof that he had an arteritis, it is a possibility. The diminution in arterial calcification seen in this case coincided with increasing mobilization and continuance of prednisolone treatment.

\section{Summary}

A 17-year-old youth, who had a protracted illness with features of ulcerative colitis, nephrosis, and arthropathy, developed calcification of the anterior and posterior tibial arteries which became less after treatment with prednisolone and mobilisation.

The possible causes of this rare phenomenon are discussed.

We wish to thank Dr. J. Ronald and Dr. E. A. Johnston for allowing access to their case records and we are indebted to Mr. Hunt for the photographs.

\section{REFERENCES}

Forsyth, C. C. (1960). Arch. Dis. Childh., 35, 296 (Calcification of the digital vessels in a child with rheumatoid arthritis).

Gardner, D. L. (1965). "Pathology of the Connective Tissue Diseases." Arnold, London.

Hudson, R. E. B. (1965). "Cardiovascular Pathology", vol. 1. Arnold, London.

Hunt, A. C., and Leys, D. G. (1957). Brit. med. J., 1, 385 (Generalized arterial calcification of infancy).

Ivemark, B. I., Lagergren, C., and Ljungqvist, A. (1962). Acta paediat., Suppl. 135, p. 103 (Generalized arterial calcification associated with hydramnios in two stillborn infants).

Meurman, L., Somersalo, O., and Tuuteri, L. (1965). Ann. paediat. Fenn., 11, 19 (Sudden death in infancy caused by idiopathic arterial calcification). 
Calcification artérielle associée a un désordre du tissu conjonctif

RÉSUMÉ

Un jeune homme de 17 ans, atteint d'une maladie prolongée avec des signes de colite ulceérative, de néphrose et d'arthropathie développa une calcification des artères tibiales antèrieure et postérieure. Cette calcification diminua après traitement par la prednisolone et la mobilisation.

On discute les causes possibles de ce rare phénomène.
Calcificación arterial asociada a un disturbio del tejido conectivo

\section{SUMARIO}

Un jóven de 17 años, sufriendo de una enfermedad prolongada con manifestaciones de colitis ulcerativa, de nefrosis y de artropatía, desarrolló una calcificación de las arterias tibiales anterior y posterior. Esta calcificación disminuyó después del tratamiento con prednisolona y movilización.

Se discuten las causas posibles de este raro fenómeno. 